\title{
A note on the ecology and management of old-growth forests in the Montane Cordillera ${ }^{1}$
}

\author{
by André Arsenault ${ }^{2}$
}

The Montane Cordillera ecozone that spans British Columbia's central and southern interior and a portion of southwestern Alberta contains the greatest variety of old-growth coniferous forest types in Canada. The diverse climates of this region, which include some of the driest, warmest, wettest, and coldest found in southern continental Canada, have directly contributed to the richness of old forest types. Associated with this range in climatic conditions are radically different natural disturbance regimes that have profoundly influenced the distribution, abundance, and structural characteristics of old-growth forests. Old forests tend to be more abundant and to contain more old-growth-dependent organisms in wetter climates. The high number of old-growth-dependent epiphytic lichens in old inland rainforests is a clear expression of this phenomenon. Conversely, old forests are much less abundant in dry landscapes. These forests, often dominated by Ponderosa pine (Pinus ponderosa P. Laws. ex C. Laws.) and Douglas-fir (Pseudotsuga menziesii (Mirb.) Franco), have been subject to more frequent natural disturbances, and have been more profoundly influenced by human activities. Although fewer species appear to be dependent on old growth in dry forests, a number of them require certain old-growth structural attributes for their survival. A better understanding of the ecological characteristics of the old-growth forests of Canada's Montane Cordillera will assist in developing informed land-use decisions.

Key words: old-growth forest, Montane Cordillera, natural disturbance, landscape ecology and management

L'écozone de la cordillère montagnarde, qui couvre la partie intérieure centrale et méridionale de la Colombie-Britannique ainsi qu'une fraction du Sud-Ouest de l'Alberta, renferme la plus grande diversité de peuplements forestiers conifériens anciens au Canada. Le climat varié de cette région, qui, à certains endroits, se classe parmi les plus secs, les plus chauds, les plus humides et les plus froids de la partie continentale méridionale du Canada, a directement contribué à la richesse des vieilles forêts. Il s'accompagne de régimes de perturbations naturelles très différents qui ont profondément influencé la distribution, l'abondance et les caractéristiques structurales des forêts anciennes. Sous les climats plus humides, les vieilles forêts ont tendance à être plus abondantes et à contenir plus d'organismes qui dépendent des forêts anciennes. Le nombre élevé de lichens épiphytes dépendant de forêts anciennes dans les vieilles forêts humides intérieures témoigne clairement de ce phénomène. Inversement, dans les paysages secs, les vieilles forêts sont beaucoup moins abondantes. Dans ces forêts, le pin ponderosa (Pinus ponderosa P. Laws. ex C. Laws.) et le douglas (Pseudotsuga menziesii (Mirb.) Franco) dominent, les perturbations par des agents naturels ont été plus fréquentes, et les activités humaines ont laissé une empreinte plus profonde. Bien que moins d'espèces semblent dépendre des forêts anciennes sèches, un certain nombre ont besoin de caractéristiques structurales particulières des forêts anciennes pour leur survie. Une meilleure connaissance des caractéristiques écologiques des forêts anciennes de l'écozone de la cordillère montagnarde au Canada favorisera la prise de décisions plus éclairées concernant l'utilisation du territoire.

Mot clés : forêt ancienne, Cordillère montagnarde, perturbation naturelle, écologie et aménagement du paysage

\section{Introduction}

Old-growth forests have been exploited for a long time. However, it is only recently that they have captured the attention of ecologists and have become one of the most controversial topics in natural resource management. Historically, professional foresters often described old-growth forests in negative terms, such as "decadent" and "overmature," favouring their replacement with young productive plantations. This stance has strongly influenced management policies for old-growth forests in western North America. An excellent example of this can be found in an excerpt from the Royal Commission on Forestry in British Columbia: "These types of stands, adding little or no net increment and which, if allowed to stand, are losing what little value they may have and with no possible chance of a future increase in later years, should, if possible, be liquidated for what they will bring before becoming so decadent and disease-

\footnotetext{
${ }^{1}$ Paper presented at the "Old-growth Forests in Canada: A Science Perspective" Conference, October 14-19, 2001, Sault Ste. Marie, ON.

${ }^{2}$ Silviculture Systems Researcher, British Columbia Forest Service, Southern Interior Region. E-mail: andre.arsenault@gems8.gov.bc.ca
}

ridden that only a salvage operation could be considered" (Sloan 1956). This view has been challenged by scientific studies that have shown the intricate relationships between forest structure (large trees, snags, and logs), ecosystem function, and biological diversity in old-growth forests (Franklin et al. 1981). In British Columbia (BC), the importance of maintaining old-growth attributes in managed land-

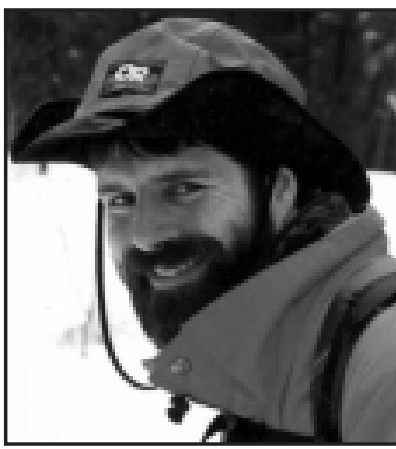

André Arsenault scapes is now relatively well accepted and has affected some changes in forest policy (BC Ministry of Forests and BC Environment 1995). However, the decline of old-growth forests resulting from the cumulative impact of natural and anthropogenic disturbances is making their conservation and that of old-growth-dependent species increasingly challenging.

The Montane Cordillera ecozone (Fig. 1) that spans British Columbia's central and southern interior (90\%) and a portion 


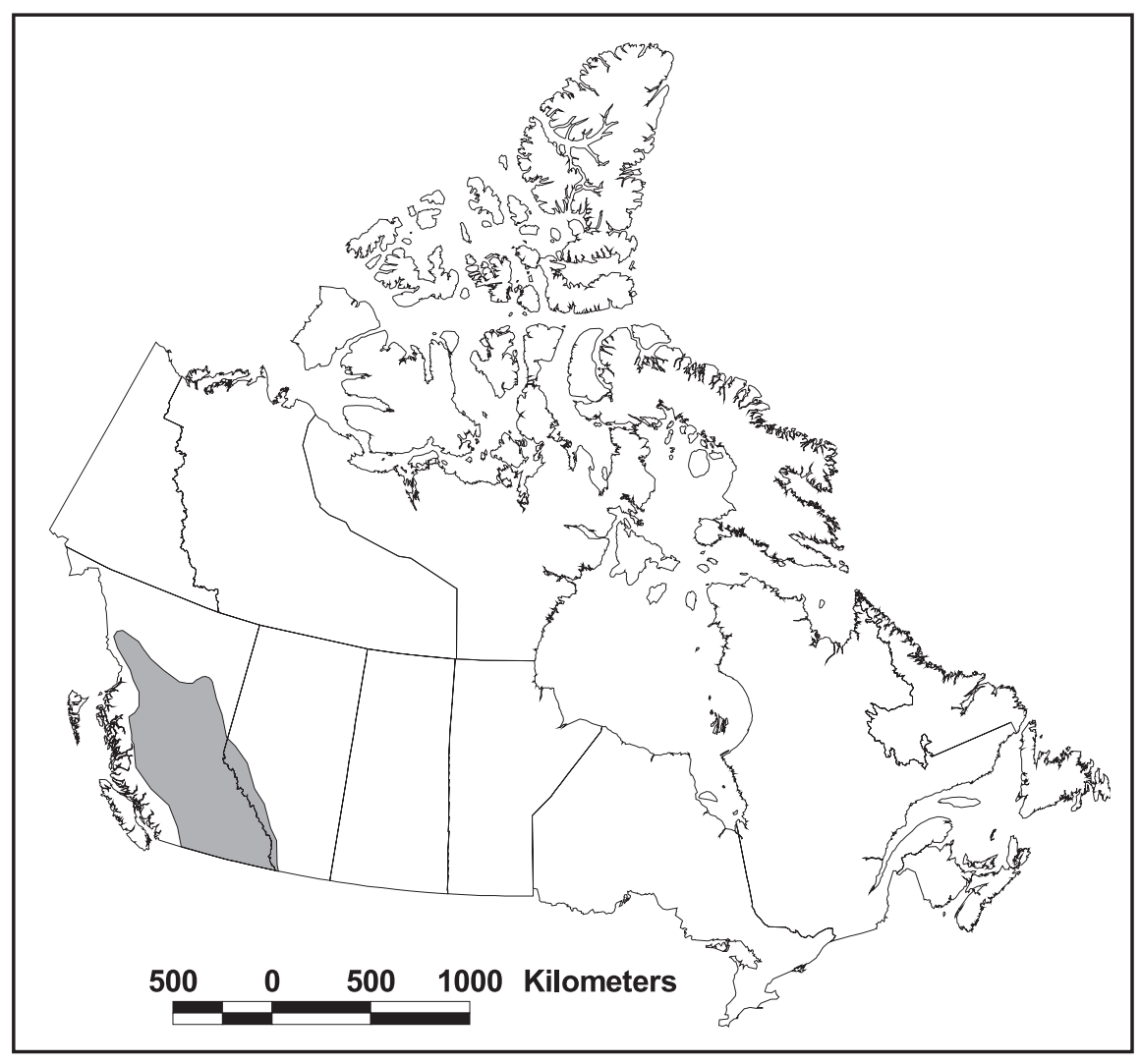

Fig. 1. Map showing the distribution of the Montane Cordillera ecozone of Canada.

of southwestern Alberta (10\%) contains the greatest variety of old-growth coniferous forest types in Canada. Old-growth forests and late-seral grasslands are recognized as important ecosystem conditions that should be maintained in the Montane Cordillera. Specific recommendations for old-growth forest retention in landscapes have been made in several recent documents: the old-growth strategy for British Columbia (BC Ministry of Forests 1992), the biodiversity guidebook (BC Ministry of Forests and BC Environment 1995), and the landscape unit planning guide (BC Ministry of Forests and Ministry of Environment, Lands and Parks 1999). Strategic conservation initiatives for old-growth forests comparable to those in British Columbia have not been initiated in Alberta. Fortunately, most of Alberta's portion of the Montane Cordillera ecozone is situated in Banff and Jasper National Parks and in the Willmore Wilderness Area, where some degree of protection is afforded.

Although many scientific studies have attempted to define old-growth forests, this task is somewhat arbitrary, as there are often no sharp ecological thresholds (Arsenault 1995, Hunter and White 1997). Furthermore, the interpretation of whether a forest is old growth or not is often affected by the ecologist's understanding of the natural disturbance regime and forest dynamics. The divergent views about the historical dynamics and characteristics of the old-growth, dry, Douglas-fir (Pseudotsuga menziesii (Mirb.) Franco) forests of southern British Columbia provide an excellent example of this (Arsenault and Klenner 2001). Earlier discussions about defining climax (Drury and Nisbet 1973) or naturalness (Sprugel 1991) faced similar challenges.

The ecosystems at the environmental extremes of the Montane Cordillera are where the most pressing old-growth management issues currently exist. In the dry belt, a long history of forest harvesting, livestock grazing, and human settlement have left very few unmanaged forests and grasslands. Most drybelt landscapes do not meet old-growth retention targets originally set in the biodiversity guidebook. The old-growth inland rainforests are found exclusively in the wetbelt of BC and are home to a unique assemblage of organisms. The cumulative impact of forest harvesting, hydroelectric developments, and natural disturbances are steadily reducing the extent of old-growth inland rainforests and placing at increasing risk the organisms that depend upon them (Arsenault and Goward 2000).

This paper provides an overview of the ecology and management of the old-growth forests of the Montane Cordillera, with emphasis on ecosystems found in British Columbia. The main objectives are to: 1) examine the ideas behind oldgrowth definitions and attributes, 2) describe some of the dominant old-growth forest types of the Montane Cordillera, with emphasis on dry forests and inland rainforests, 3) challenge the concept of fire-maintained old-growth forests in the dry belt, and 4) discuss forest management issues from the perspective of old-growth-dependent species.

\section{Old-growth Definitions and Attributes}

The establishment of objectives for old-growth retention and management requires a definition, or at a minimum, a certain level of agreement on what constitutes an old-growth forest. In British Columbia, for practical reasons the forest inventory stand age is typically used to determine whether a forest has reached the old-growth stage. As illustrated below, no matter what approach is used when defining old growth, limitations will arise and ecological principles should be used to designate old-growth forests for retention ( $c f$. Klenner and Arsenault, in prep.). 
Although many ecologists, foresters, and environmentalists have a certain vision of what constitutes an old-growth forest, the relative nature of the term has yielded a wide range of definitions and descriptions (Arsenault 1995, Wells et al. 1998). Terms like "pristine," "overmature," or "decadent" clearly reflect a value gradient, often associated with polarized positions in forest management. Different perspectives on ecosystem disturbance and patch dynamics will strongly influence how ecologists view the world and describe old-growth forests. For example, the monoclimax theory is deterministic, based on the convergence of plant communities toward a single and predictable endpoint (Whittaker 1975). Ecologists adopting this paradigm will often have a narrow and singular definition of old-growth forests.

The contemporary view of ecosystem dynamics recognizes the loose arrangement of plant communities (Drury and Nisbet 1973), the importance of natural disturbances (Watt 1947, Pickett and White 1985), and the role of initial floristic composition (Egler 1954) in creating multiple possible endpoints in succession (e.g., old growth). These different conditions of old-growth forests are reflected in the variation of species composition (McCune and Allen 1985) and forest structure (Arsenault and Bradfield 1995) in older forest types located on similar sites. Similar conclusions have been reached for grasslands and rangelands in the literature.

Old growth was defined by Oliver (1981) as the stage at which the original tree cohort that established following a catastrophic disturbance is completely replaced by a new one through uninterrupted succession. This demographic definition of old growth (Wells et al. 1998) is useful but fairly exclusive. It precludes the possibility of developing old growth on sites where the interval between catastrophic disturbances is shorter than the life span of establishing species. For example, an old forest still dominated by the original cohort that established after a catastrophic fire 300 years ago would not meet Oliver's old-growth criteria. Similarly, old stands with multiple cohorts resulting from partial disturbances would also fail this old-growth standard. Although many of the old coastal rainforests would pass this old-growth test, most old-growth forests in the Montane Cordillera would not. Generally, disturbances are more frequent in the Montane Cordillera than on the coast. As a result, trees rarely attain their maximum age in old forests. Furthermore, many of the old forests in the dry belt have multiple cohorts associated with insect defoliation and fire events. Exceptions are found, however, particularly in the inland rainforests, which share many similarities with coastal forests (Arsenault and Goward 2000) and in some high-elevation fir-spruce forests (Antos and Parish 2002), which appear to have reached a steady state.

Franklin et al. (1981) proposed a more inclusive, but vague, definition for old growth: "forest ecosystems that have developed over a long period essentially free of catastrophic disturbances." Recent definitions have focused on structural attributes characteristic of older forests, such as the one developed by the BC old-growth strategy (BC Ministry of Forests 1992): "Old growth is a forest that contains live and dead trees of various sizes, species composition, and age class structure that are part of a slowly changing but dynamic ecosystem." Similar definitions have been developed in the United States (Kaufmann et al. 1992). Although this type of definition facilitates communication on old-growth management issues, it has the disadvantage of not being very specific for identifying old- growth forests on the landscape or for developing explicit management objectives.

There is no simple, right way of classifying a forest as old growth or not old growth because there are no clear thresholds for when a forest becomes old (Hunter and White 1997). In British Columbia, we have developed working definitions based on arbitrary old-growth thresholds using inventory forest age as a proxy. Although it is not a perfect method, it has been very useful operationally, allowing for the strategic identification of old-growth management areas in landscapes. Other approaches for defining old-growth forests have used structural attributes from inventories and determined arbitrary thresholds for when a forest is considered old growth. Such criteria have been developed for old-growth Douglas-fir and the mixed conifer forests of the Pacific Northwest (Old-growth Definition Task Group 1986), for major forest types of the Rocky Mountain Region (Mehl 1992), for old forests from British Columbia's Sub-boreal Zone (Kneeshaw and Burton 1998), and for the dry forests of the Nelson Forest Region (Steeger et al. 2000). Although these definitions of old growth may appear more rigorous because they are based on empirical data, often obtained from forest inventories, they also suffer from a subjective definition of old growth.

The notion that there are no clear thresholds for oldgrowth forests has led some authors to develop indices representing the variation of "old growthness" based on multivariate summaries of structural attributes (e.g., Spies and Franklin 1988, Holt et al. 1999). This approach offers interesting possibilities in that forests can be scored for different levels of old growthness. However, this method is not perfect either as the quality of the index will depend strongly on the data used in its construction. Ideally, a wide range of old-growth types on similar sites should be used to capture the true nature of the variation. Some of the disadvantages of this method are that the scientists constructing the index must select a given set of attributes, thus filtering the complexity of the forests into a few variables. The process used for filtering depends on the ecologist's understanding of the system. A more rigorous and systematic process for selecting attributes would probably improve their usefulness. For example, although the emphasis of these old-growth indices is usually placed on forest structure, the time since disturbance is actually the most important variable for certain species, such as some epiphytic lichens in some forest ecosystems (Rose 1976, Selva 1994, Goward and Arsenault, in prep.). Again, there is a certain level of subjectivity with the construction of old-growth indices in the selection of attributes to be measured, in the selection of the mathematical model used to construct the index, and in the application of the index. Finally, scoring old-growth forest candidates for retention is a necessary step in forest planning; however, instead of trying to find the best stand in every case that matches the ideal image of what an old-growth forest should be, it would be astute to consider a broader range of ecological conditions to optimize ecological representation.

Age-based and attribute-based definitions for old-growth forests are both subjective and cannot be tested. In the face of this uncertainty, it is critical to: (1) appreciate the intent behind establishing old-growth management areas (i.e., complement the stand structure conditions that would develop in a managed forest), (2) appreciate the complexity of ecosystem disturbance and succession processes, and (3) maintain a variety of conditions that 
likely encompass the range of habitat types that likely represent old growth, rather than subscribing to a singular and monolithic view.

\section{Ecosystem Variation in the Montane Cordillera}

The Montane Cordillera is one of the most diverse ecozones of Canada. Thirteen of the 14 Biogeoclimatic Zones in British Columbia are represented in this ecozone (see Fig. 10 in Meidinger and Pojar 1991). This high level of ecosystem diversity is primarily the result of three important gradients.

1) Orographic precipitation, resulting from the tall mountain ranges making up the Cordillera, has produced a series of dry-belt and wet-belt vegetation types.

2) Vegetation also changes radically with elevation, from forests in valley bottoms to the Alpine Tundra.

3) Finally, ecosystem types change significantly along the latitudinal gradient from semi-deserts near the US border to sub-boreal forests in the northern part of the ecozone.

Associated with these gradients are important differences in natural disturbance regimes. For example, fire-return intervals can vary from 15 years in some dry forests to over 300 years in the wet belt.

The diversity of ecosystems in the Montane Cordillera is potentially very high, depending on what level of resolution is used (Fig. 2). The number of common forested ecosystems at the site series level in the Montane Cordillera exceeds 600. The number of old-growth forest types that could potentially be described would be substantially higher if rare communities and different structural types were included. I propose that it is not realistic to develop specific old-growth forest definitions for each ecosystem type, given the great variety of old-growth forest types in the Montane Cordillera.

Gymnosperms dominate in number of species over angiosperms in each biogeoclimatic zone of the Montane Cordillera (Fig. 3). The richest and most productive zone is the Interior Cedar Hemlock Zone. All dominant coniferous tree species in the Montane Cordillera can form or be associated with old-growth forests (> 200 years). In contrast, most stands dominated by broadleaf species are generally in the early to mid-seral stages of development. The most extensive and oldest forests (300 to $>900$ years) are found in the wet belt (ICH and ESSF biogeoclimatic zones) as a result of less frequent, catastrophic disturbances. Several tree species are at the edge of their range and occur in only one or two of the nine dominant biogeoclimatic zones (Table 1).

\section{Examples of Dominant Old-growth Types in the Montane Cordillera}

This section is intended to succinctly describe some of the dominant old-growth types in the Montane Cordillera. As mentioned earlier, the high degree of ecosystem diversity prohibits a comprehensive description at least within the scope of this paper. More detailed descriptions of vegetation in the Montane Cordillera can be found in Lloyd et al. (1990), Meidinger and Pojar (1991), Braumandl and Curran (1992), Banner et al. (1993), Delong et al. (1993, 1994), Delong (1996a, b), and Steen and Coupé (1997), for British Columbia and in Achuff (1989) and Timoney (2001) for Alberta.

\section{Interior dry belt}

In many landscapes of the interior dry belt, distinctive vegetation zones can be recognized along an elevation gradient.

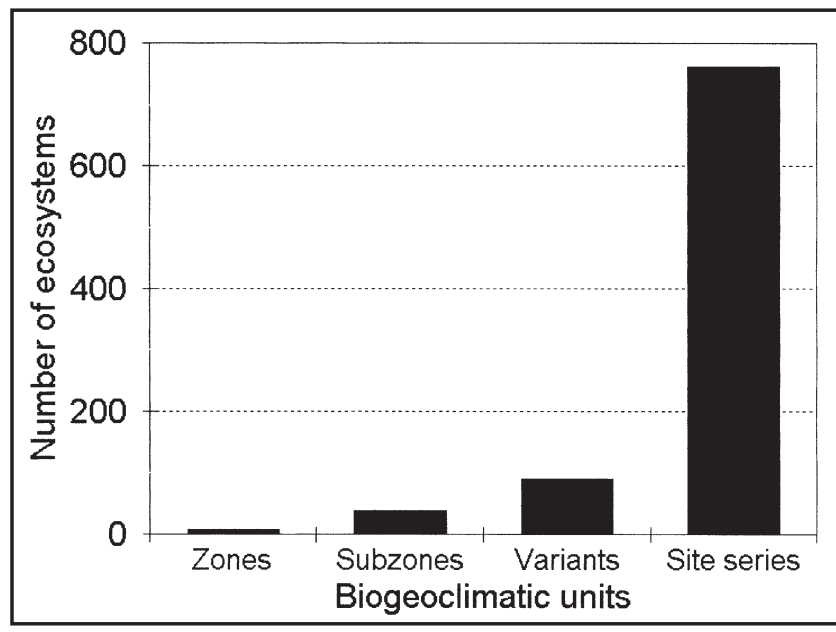

Fig. 2. Ecosystem diversity in the Montane Cordillera.

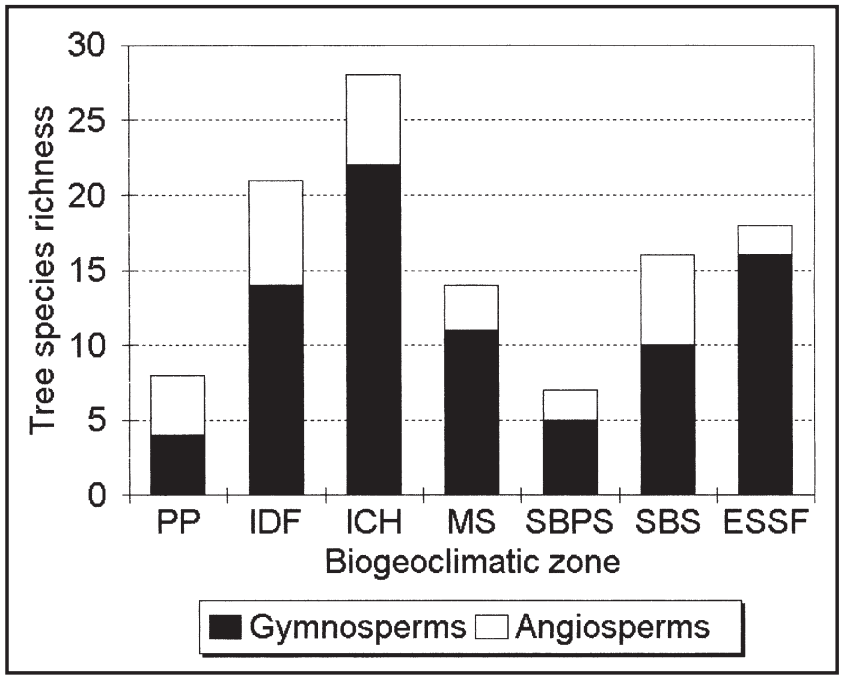

Fig. 3. Tree species richness in the dominant biogeoclimatic zones of the Montane Cordillera.

Grasslands and Ponderosa pine forests at low elevations gradually change to monospecific Douglas-fir forests on mid to upper slopes, which eventually give way to hybrid white spruce (Picea glauca (Moench) Voss) and lodgepole pine (Pinus contorta Dougl. ex Loud.) forests on the high plateaus.

\section{Grasslands}

Late-seral grasslands of the Bunch Grass Zone are considered rare in the Montane Cordillera. The cumulative impact of severe overgrazing by horses, cattle, and sheep in the late 1800s and early 1900s, of indiscriminate use of pesticides against grasshoppers, of exotic plant invasions often associated with ground disturbance, and of urban and rural encroachment has made late-seral grasslands one of the most threatened ecosystems in the Montane Cordillera. Late-seral grasslands are now largely restricted to isolated areas where there is poor access for livestock or motorized vehicles. Generally rich biocrust communities composed of lichens, bryophytes, and cyanobacteria cover the soil surface. Abundant bunchgrasses and grass litter are also often characteristic of these ecosystems (Fig. 4). 
Table 1. Distribution of 23 species of conifers and nine species of broadleaf trees in the eight dominant forested biogeoclimatic zones ${ }^{1}$ of the Montane Cordillera. Adapted from Pojar and Meidinger (1991). The occurrence of tree species are: (+) rare, + present but uncommon, ++ common, and +++ abundant.

\begin{tabular}{|c|c|c|c|c|c|c|c|c|}
\hline Species & BG & $\mathbf{P P}$ & IDF & ICH & MS & SBPS & SBS & ESSF \\
\hline Abies amabilis & & & & $t^{2}$ & & & & \\
\hline Abies grandis & & & ++ & ++ & + & & & \\
\hline Abies lasiocarpa & & & & ++ & +++ & $(+)$ & +++ & +++ \\
\hline Chamaecyparis nootkatensis & & & & & & & & $(+)$ \\
\hline Juniperus scopulorum & + & + & ++ & & & & + & \\
\hline Larix laricina & & & & & & & $(+)$ & \\
\hline Larix lyalii & & & & & & & & ++ \\
\hline Larix occidentalis & & + & +++ & ++ & +++ & & & + \\
\hline Picea engelmanii & & & + & ++ & +++ & & & +++ \\
\hline Picea engelmanii x glauca & & $(+)$ & ++ & ++ & +++ & + & +++ & ++ \\
\hline Picea glauca & & $(+)$ & + & & + & +++ & ++ & + \\
\hline Picea glauca $x$ sitchensis & & & & $++^{2}$ & & & & \\
\hline Picea mariana & & & & + & & & ++ & \\
\hline Pinus albicaulis & & & & & & & & +++ \\
\hline Pinus contorta & $(+)$ & & +++ & ++ & +++ & +++ & +++ & +++ \\
\hline Pinus flexilis & & & $(+)$ & & & & & $(+)$ \\
\hline Pinus monticola & & & + & ++ & + & & & + \\
\hline Pinus ponderosa & + & +++ & +++ & + & & & & \\
\hline Pseudotsuga menziesii & + & ++ & +++ & ++ & +++ & + & ++ & + \\
\hline Taxus brevifolia & & & $t^{3}$ & $++^{3}$ & & & & \\
\hline Thuja plicata & & $(+)$ & ++ & +++ & + & & + & + \\
\hline Tsuga heterophylla & & & + & +++ & + & & $(+)$ & + \\
\hline Tsuga mertensiana & & & & + & & & & ++ \\
\hline Acer macrophyllum & & & + & & & & & \\
\hline Betula occidentalis & + & + & + & $(+)$ & & & $(+)$ & \\
\hline Betula papyrifera & + & + & ++ & ++ & + & & ++ & \\
\hline Cornus nutalii & & & + & & & & & \\
\hline Populus balsamifera ssp. Balsamifera & & & & & & + & & \\
\hline Populus balsamifera ssp. Trichocarpa & + & + & + & ++ & + & + & ++ & + \\
\hline Populus tremuloides & + & ++ & ++ & ++ & ++ & + & +++ & + \\
\hline Prunus emarginata & & & $+^{3}$ & $++^{3}$ & & & $+^{3}$ & \\
\hline Rhamnus purshiana & & & & $++^{3}$ & & & & \\
\hline
\end{tabular}

${ }^{1}$ BG Bunchgrass Zone, PP Ponderosa Pine Zone, IDF Interior Douglas-Fir Zone, ICH Interior Cedar-Hemlock Zone, MS Montane Spruce Zone, SBPS Sub-boreal Pine-Spruce Zone, SBS Sub-boreal Spruce Zone, ESSF Engelmann Spruce-Subalpine Fir Zone.

${ }^{2}$ Tree species occur in the ICH in the northwestern part of the Cordillera and are transitional to coastal forest.

${ }^{3}$ Rarely occur as small trees in the Montane Cordillera.

\section{Dry forests}

Old-growth stands in the dry forests of the Ponderosa Pine (Fig. 5) and Douglas-fir Zones (Fig. 6) are also relatively scarce in the Montane Cordillera. Ponderosa pine forests were intensively logged in the early 1900s to make fruit boxes and lumber. In the 1920 s, concerns were already being raised about the disappearing ponderosa pine stands (Klenner et al., in prep.). The majority of old ponderosa pine forests left are those that were not easily accessible for logging. Douglas-fir stands also underwent extensive partial cutting in the mid-1900s. As a result of natural and human disturbances, there are generally not enough old, dry forests left to meet the retention targets established for British Columbia.

The conventional view of old-growth ponderosa pine and Douglas-fir forests is that of very open stands composed of large pine or Douglas-fir trees and an abundant grass understorey (Daigle 1996, Gayton 1996). This view rests on the fire-maintained ecosystems paradigm that is challenged in the next section.

\section{Montane spruce forests}

The high-elevation plateaux in many dry-belt landscapes are dominated by the Montane Spruce Zone. Historically, catastrophic fires have resulted in extensive areas of even-aged lodge- pole pine stands. Old-growth forests generally consist mainly of old lodgepole pine stands breaking up and being gradually replaced by hybrid white spruce and, to a lesser extent, subalpine fir (Abies lasiocarpa (Hook.) Nutt.) (Fig. 7). The structure in these old stands varies greatly, depending on past disturbance history and where the stands are along the successional trajectory.

\section{Wet-belt gradient}

Much of the interior wet belt is composed of old-growth forests represented by the Interior Cedar-Hemlock Zone (ICH) at low to mid-elevations and the Engelmann Spruce-Subalpine Fir Zone (ESSF) at high elevations.

\section{Interior Cedar-Hemlock forests}

Forests of the ICH are the most productive and most rich in tree species in the Montane Cordillera. There are many different types of old-growth stands in this zone, reflecting the high diversity of tree species and complex dynamics (Fig. 8). However, through succession there appears to be a strong convergence toward stands dominated by western redcedar (Thuja plicata Donn ex D. Don) and western hemlock (Tsuga heterophylla (Raf.) Sarg.) and these two species account for an important 


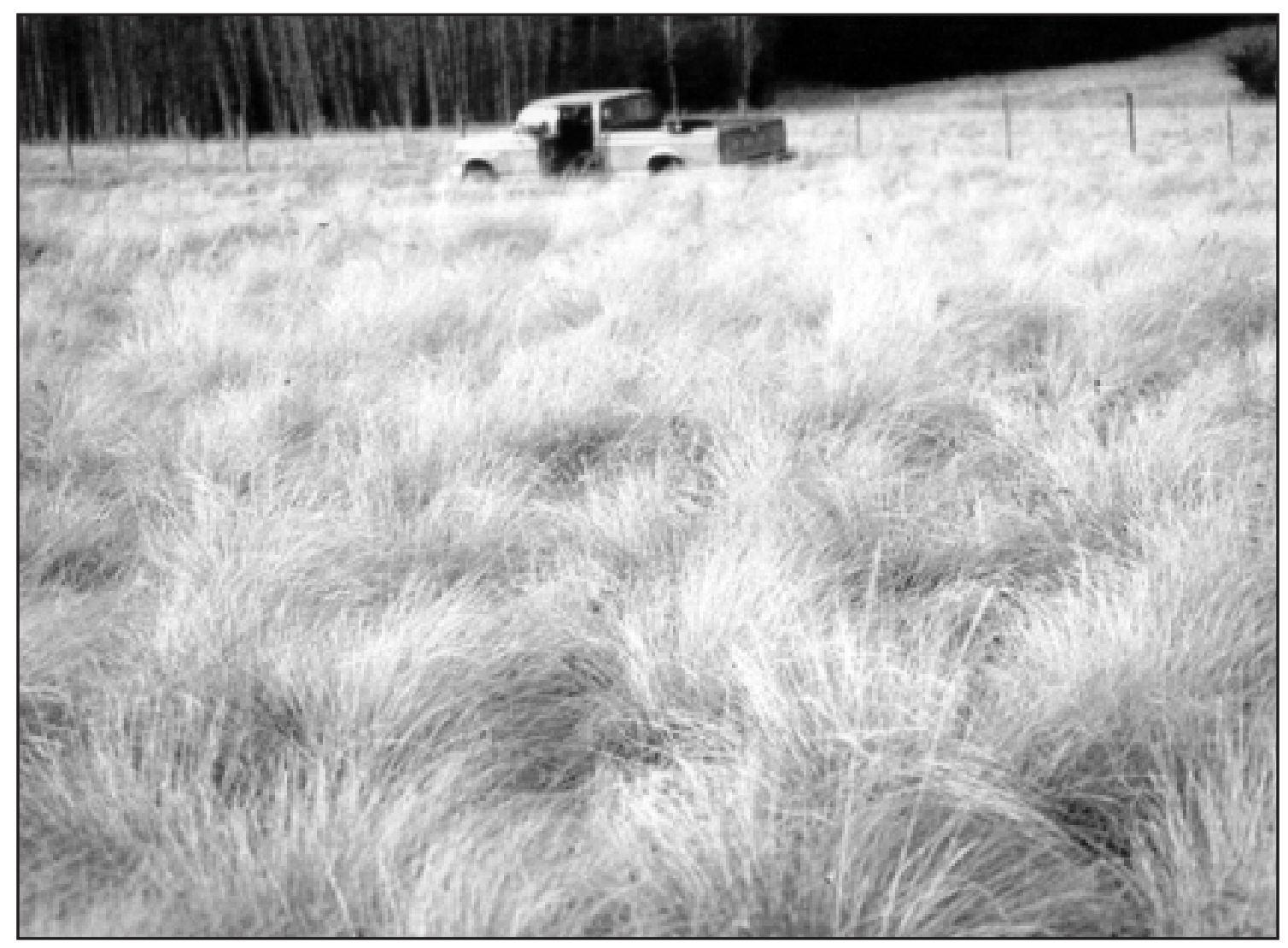

Fig. 4. Late seral grassland in southern British Columbia.

proportion of old-growth forests, particularly at the wetter extreme of the gradient. Old-growth forests are often older than 300 years and can exceed 900 years in the wetter subzones (inland rainforests). The inland rainforest phenomenon is unique to eastcentral British Columbia, being confined to the wetter subzones of the Interior Cedar-Hemlock Zone. Rainforest conditions develop inland as a result of a peak of rainfall during the middle of the growing season, and plentiful snowmelt during the early part of the growing season (Arsenault and Goward 2000). These humid conditions have enabled the development of a unique vegetation that contains many oceanic elements, including several species of lichens (Goward and Arsenault 2000a, 2000b) and bryophytes (Newmaster et al. 2003) that are restricted to old-growth forests (Fig. 9). Old-growth inland rainforests dominated by western redcedar and western hemlock closely resemble coastal temperate rainforests in the complexity of their architecture, in the lushness of their respective understoreys, and in the presence of a rich epiphytic flora.

\section{High-elevation spruce-fir forests}

At higher elevations in the wet belt, old-growth forests in the ESSF are largely dominated by subalpine fir and to a lesser extent Engelmann spruce. Some old stands still have evidence of standinitiating disturbances (Parish 1997), but others have no signs of catastrophic disturbance and appear to be in a near steady state (Antos and Parish 2002). Although some stands can be as old as the 900-year-old inland rainforests, they are less obvious because, in many cases, the trees are younger than the forests, because of the faster turnover of subalpine fir. Old-growth stands are often patchy, as a result of local disturbances and limited conditions for tree growth and regeneration. Many old-growth stands are characterized by clumps of trees, openings, many dead trees, and abundant coarse woody debris (Fig. 10). These also harbour large amounts of epiphytic hair lichens, which are an important food source for the mountain caribou (Edwards et al. 1960).

\section{Fire History and Old-growth Forests in the Drybelt}

There is a strong belief that fire suppression has drastically affected the dynamics and structure of dry forests in the Montane Cordillera. This suggests that, before fire suppression, frequent and extensive surface fires maintained old forests in open conditions with large trees and an abundant grass understorey. Many forests currently do not correspond to this vision and are, therefore, considered by some to be unhealthy and in need of restoration using a combination of logging and prescribed fire (Daigle 1996, Gayton 1996). This is a good example of how a popular, yet untested, ecological paradigm influences old-growth forest management.

The hypothesis that dry-belt forests were historically subject to a fire-maintained disturbance regime is based on limited and, in some cases, severely biased information. For example, the use of historical photographs (Gayton 1996) showing open forests and changes in tree density are interesting but have little value from an overall assessment perspective because 

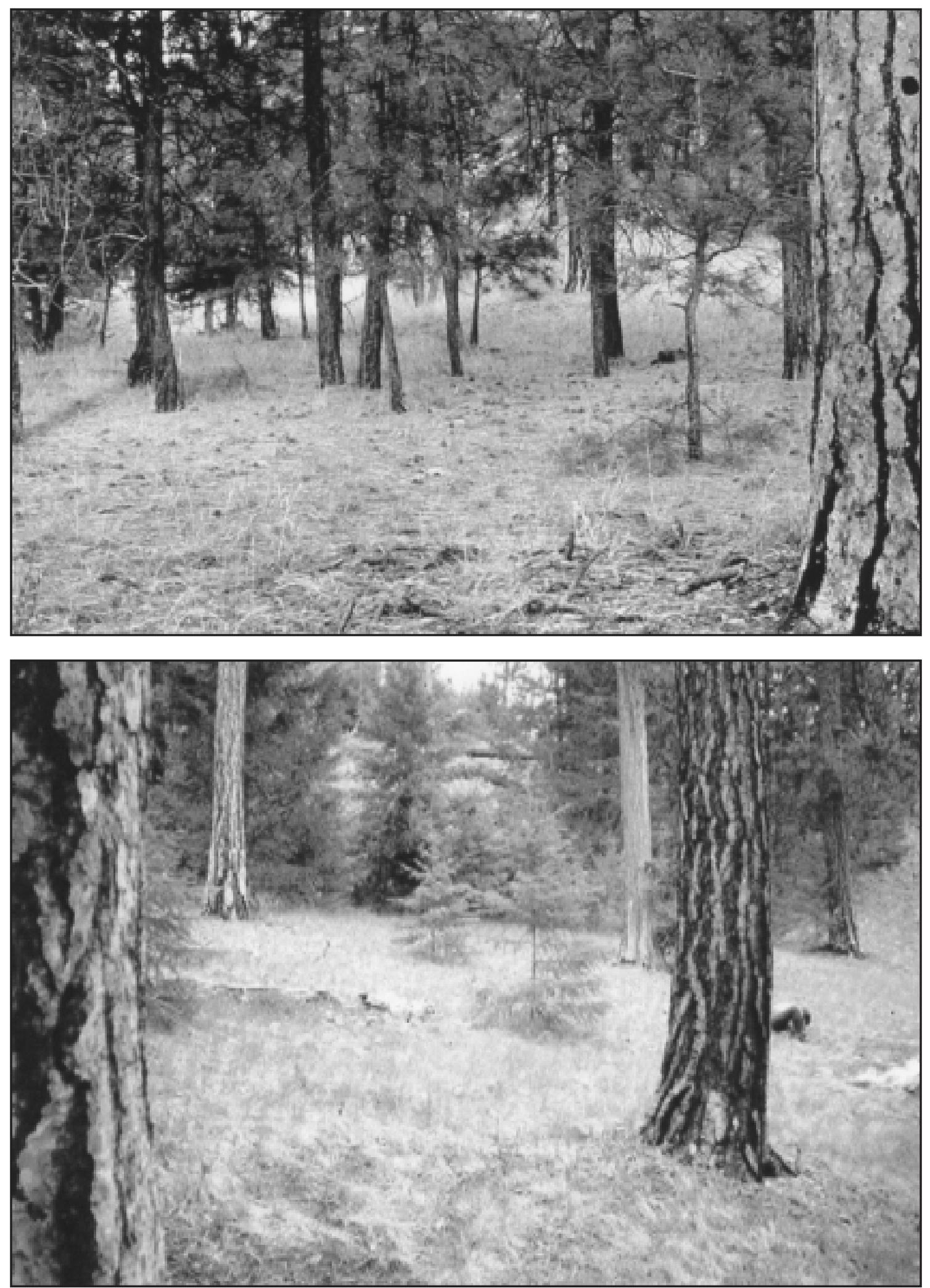

Fig. 5. Old-growth Ponderosa pine forest in southern British Columbia.

the selection of these photographs is often biased to prove a point. Furthermore, most historical photographs represent a relatively narrow period of historical conditions and there is no clear rationale why these conditions should be used as a unique reference point for what old-growth forests or grasslands should look like (Klenner et al., in prep.). 

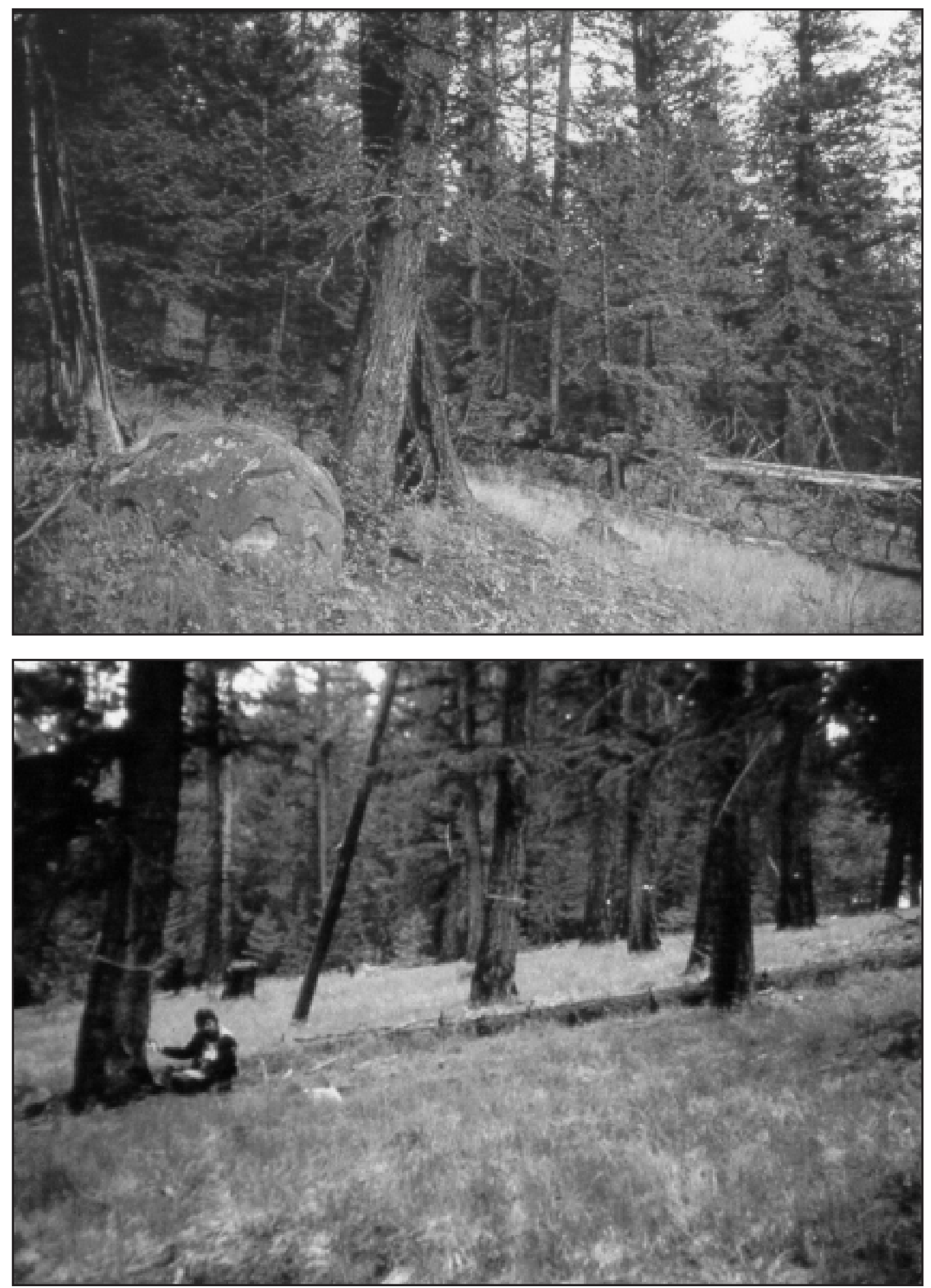

Fig. 6. Old-growth interior Douglas-fir forests in southern British Columbia.

Another line of evidence often used to support the fire-maintained hypothesis relies on fire history studies using fire-scar analysis. Although dendrochronological techniques allow dat- ing of fire events with great accuracy, the sampling methods, analysis, and interpretation generally used bias the results of fire studies in dry forests toward extensive and frequent, low- 


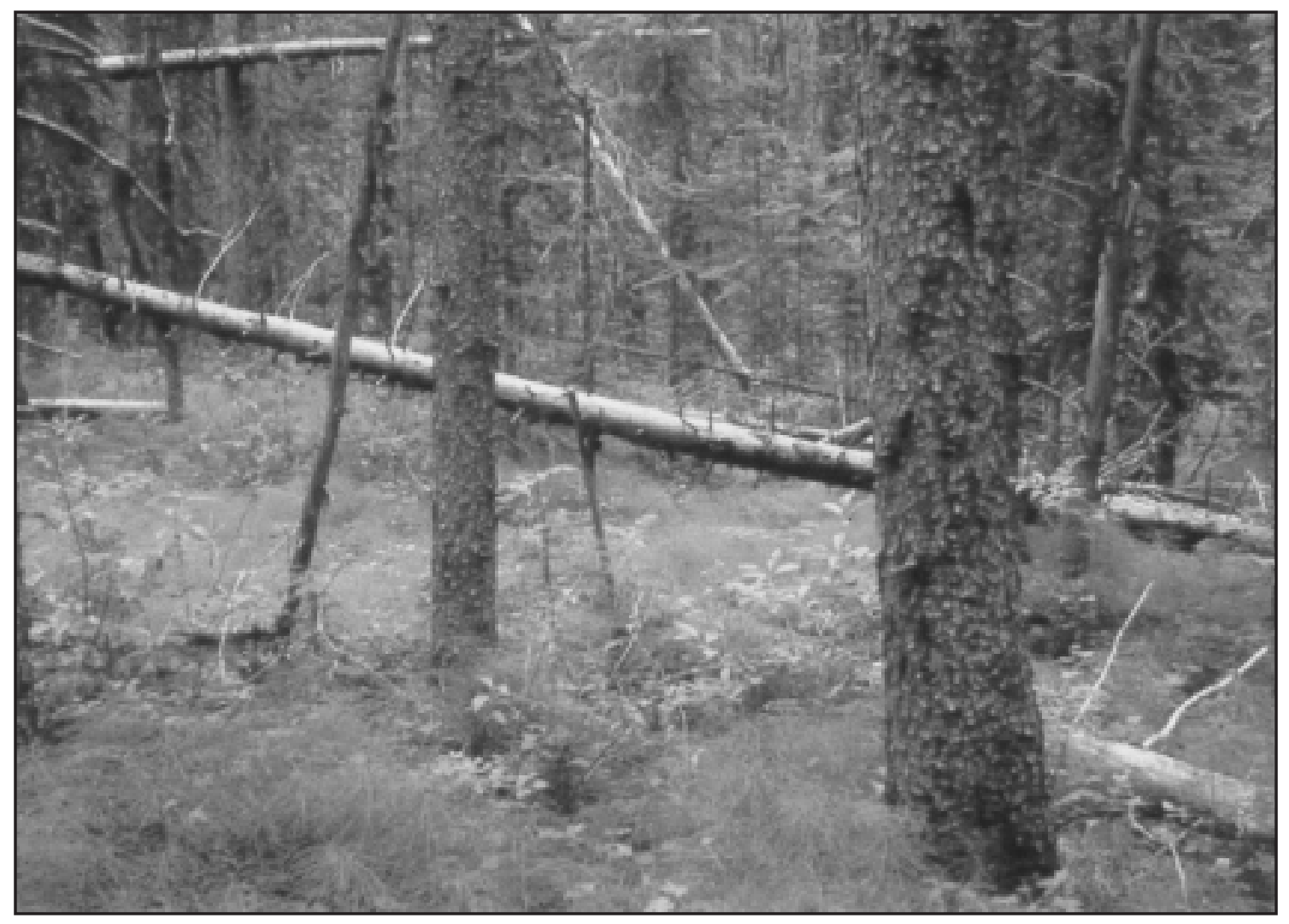

Fig. 7. Old-growth Montane spruce forests in southern British Columbia.

intensity surface fires (Arsenault and Klenner, in prep.). The problems arise from a bias in the selection of study sites and sample trees, a focus on mean fire-return interval rather than on the range of fire intervals, and an unreasonable extrapolation of data from small study areas to entire landscapes.

Studies using fire-scar analysis often bias the selection of study sites and tree samples with a preference for areas with multiple tree scars and for tree samples with the most scars. This approach inevitably results in an overestimation of the frequency and extent of low-severity surface fires (Arsenault and Klenner 2001, Baker and Ehle 2001) and in an underestimation of the occurrence of moderate and high-severity fires (Arsenault and Klenner 2001). A closer examination of fire history clearly shows that moderate and high-severity fires are an important component of the fire regime in these dry forest ecosystems (Shinneman and Baker 1997, Arsenault and Klenner, in prep.). Furthermore, an historical analysis of the seasonality of fires (1920-present) reveals that the majority of fires occurred in the months of June to August. This period generally coincides with fire weather that would lead to severe fire behaviour not conducive to maintaining ecosystems in a dynamic equilibrium (Klenner et al., in prep.).

The mean fire-return interval (MFRI) is by far the most common fire frequency statistic found in the literature on fire history of dry forest ecosystems. Although the MFRI number may give a sense of factual certainty to forest managers, it can also be very misleading unless one examines the temporal and spatial variation around the mean. For example, the MFRI in the lower Dewdrop Valley near Kamloops, BC was estimated to be 19 years (Smaill 1980). Some believe that the inter- vals between fires are now much greater, e.g., 50 years in this area as a result of fire suppression. However, the distribution of fire intervals reveals that there was a great deal of temporal variation in the pattern of fire, with intervals between fires reaching 50 years in the 1600s (Fig. 11).

These observations do not mean that low-severity surface fires did not occur, but suggests that the fire regime in dry-belt forests is complex and more representative of a mixed severity fire regime. This hypothesis suggests that old-growth stands in dry forests were historically represented by a greater variety of stand types than previously contemplated (Table 2). Hence, the concept of ecological restoration using prescribed burning or other anthropogenic interventions to recreate natural conditions in dry forests of the Montane Cordillera should be re-examined critically.

\section{Old-growth-dependent Species}

A major impetus for conserving old-growth forests or for retaining old-growth attributes in managed landscapes is that certain species require these ecosystems for their survival. The type and level of conservation initiative should depend, at least to some extent, on the type of relationship between the species and the old forests. Much attention on old-growth-associated species has been focused on charismatic vertebrates (Carey 1989), such as the northern spotted owl in the western USA (Carey et al. 1990) and the mountain caribou in British Columbia (Stevenson et al. 2001). However, the reality is that many of the organisms associated with old forests are non-vascular plants and invertebrates - groups generally less well known to wildlife biologists and the general public. In particular, some epiphytic lichens have 

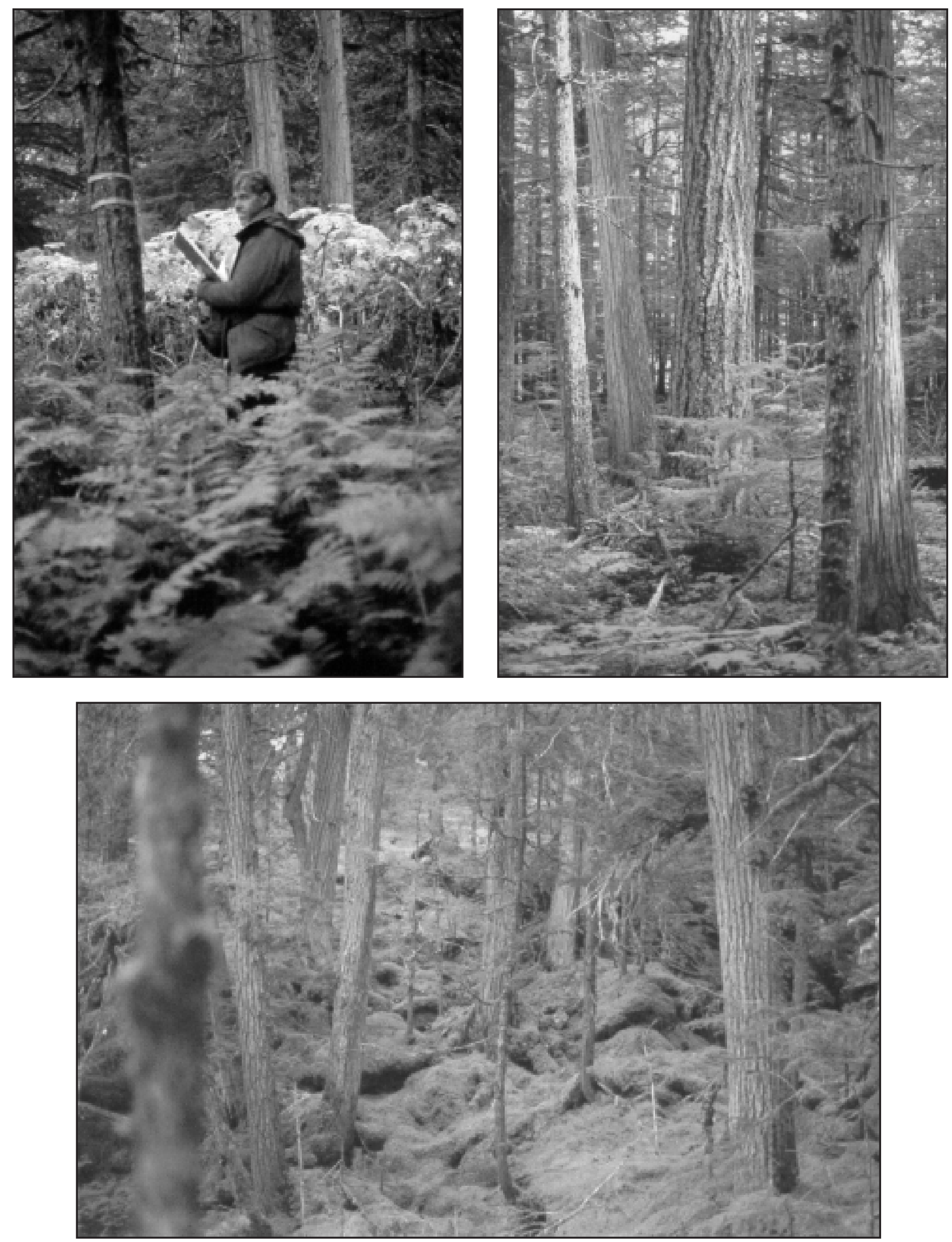

Fig. 8. Old-growth interior cedar-hemlock in south central British Columbia forests. 


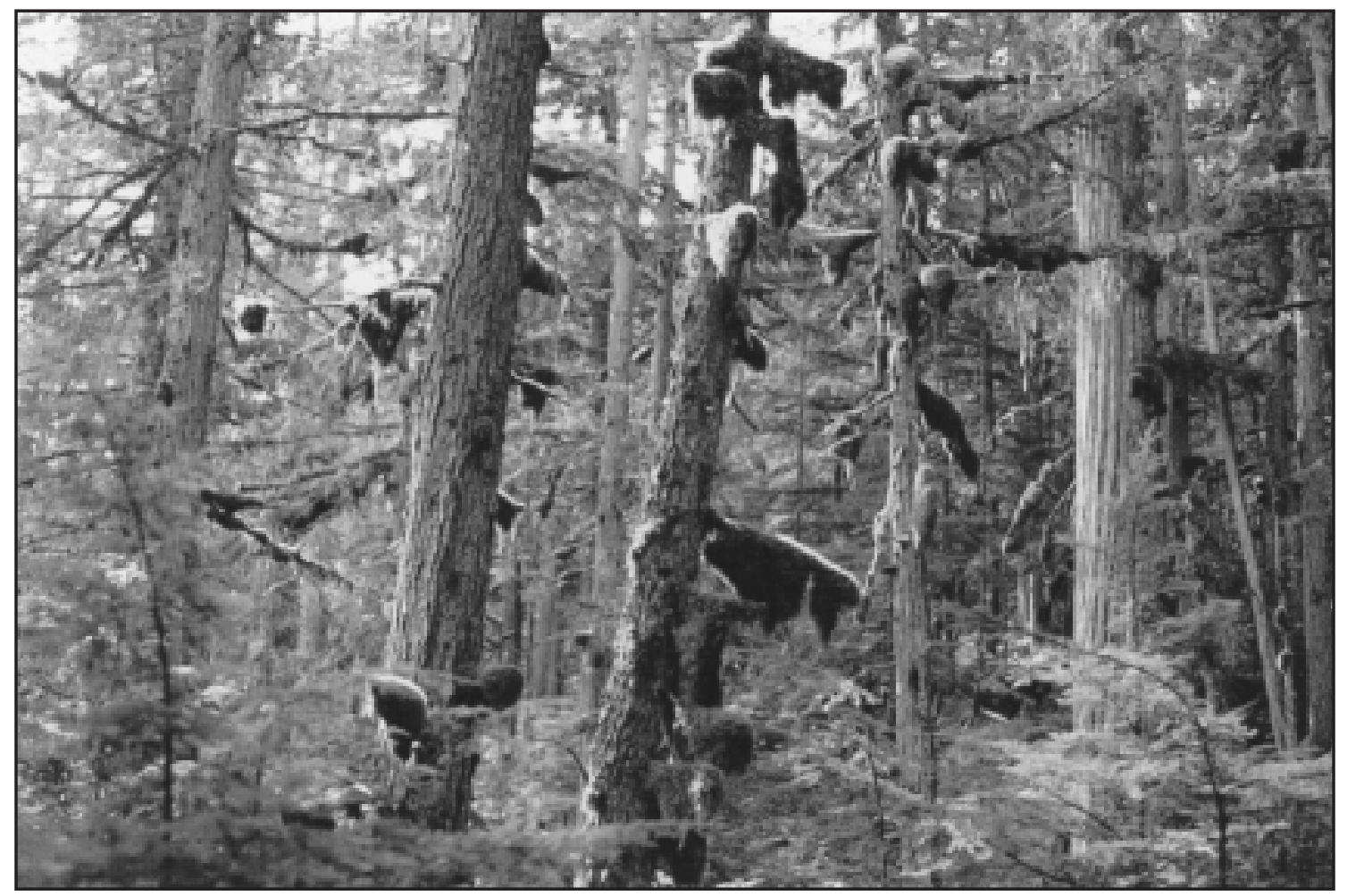

Fig. 9. Old-growth inland rainforest, Rainbow Falls, Wells Gray Provincial Park.

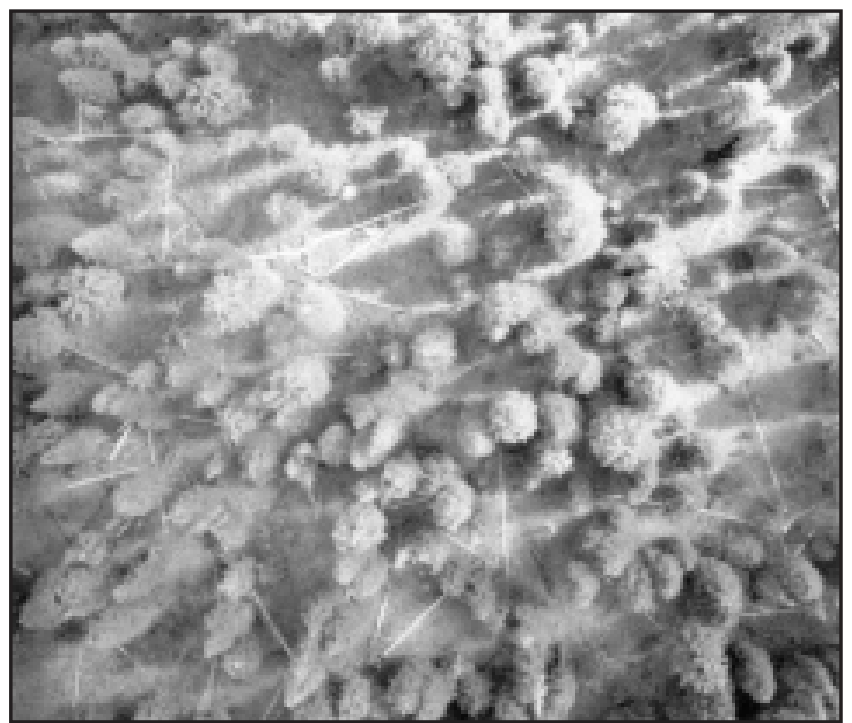

Fig. 10. Old-growth fir-spruce forest in south-central British Columbia.

been shown to be good indicators of old forest conditions (Rose 1976, Tibell 1992, Selva 1994, Goward and Arsenault 2000b). Similar observations have been made for bryophytes (Söderström 1988, Newmaster et al., in press). The management implications of recent observations made on lichen species and their relationships with old forests in the Interior Cedar-Hemlock Zone portion of the Cordillera are presented below. (Arsenault and Goward, in prep., Goward and Arsenault, in prep.).

Some species are dependent on old-growth forests because of certain habitat components (level 1 old-growth species), e.g., large live and dead trees, large logs, and root mounds.

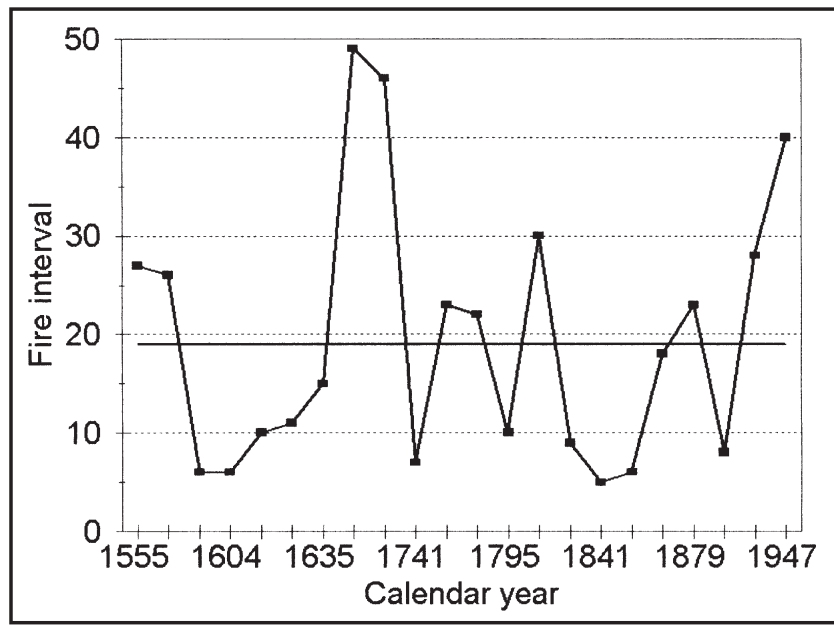

Fig. 11. Temporal distribution of fire intervals from the lower Dewdrop valley near Kamloops.

In these cases, leaving remnant old-growth structures in managed stands may be sufficient to maintain these organisms. Other species require specialized microclimates (level 2 old-growth species) associated with old forests. Conservation of these species would require the retention of forest patches that conserve the microclimatic characteristics associated with old forests, especially at the edges of their range. Finally, some species will simply require old-growth conditions to be present for a very long time before they can be established and develop (level 3 old-growth species). These organisms will usually be associated with very old, old-growth forests (antique), where the forest may be much older than the age of the oldest living trees. 
Table 2. Generalized old-growth characteristics under three different fire regime that characterize dry-belt Douglas-fir forests (from Arsenault and Klenner, in prep.)

\begin{tabular}{|c|c|c|c|}
\hline \multirow[b]{2}{*}{ Attribute } & \multicolumn{3}{|c|}{ Fire regime according to severity categories } \\
\hline & Low severity & Mixed severity & High severity \\
\hline Old live trees (old for the site) & $>50 \%$ of dominant tree layer & $>50 \%$ of dominant tree layer & $>50 \%$ of dominant tree layer \\
\hline $\begin{array}{l}\text { Live but declining (decay, } \\
\text { breakage, dead tops) trees large } \\
\text { for the site }\end{array}$ & Common & Common & Common \\
\hline Dead trees, large for the site & Common & Common & Common \\
\hline Litter $^{1}$ & Very low levels & Moderate to high levels & Moderate to high levels \\
\hline Biocrust $^{1}$ & $\begin{array}{l}\text { Well developed in grasslands and } \\
\text { dry forests, but sensitive to trampling } \\
\text { by cattle }\end{array}$ & $\begin{array}{l}\text { Well developed in grasslands and } \\
\text { dry forests, but sensitive to trampling } \\
\text { by cattle }\end{array}$ & $\begin{array}{l}\text { Well developed in grasslands and } \\
\text { dry forests, but sensitive to trampling } \\
\text { by cattle }\end{array}$ \\
\hline Graminoids $^{1}$ & $\begin{array}{l}\text { Well developed in openings with } \\
\text { low densities of understorey woody } \\
\text { plants. Relatively low abundance of } \\
\text { dead grasses }\end{array}$ & $\begin{array}{l}\text { Well developed in openings with } \\
\text { low densities of understorey woody. } \\
\text { plants. Moderate to high levels of } \\
\text { dead grasses }\end{array}$ & $\begin{array}{l}\text { Well developed in openings with low } \\
\text { densities of understorey woody } \\
\text { plants. Moderate to high levels of } \\
\text { dead grasses }\end{array}$ \\
\hline Shrubs $^{1}$ & $\begin{array}{l}\text { Fire-sensitive species will have a } \\
\text { more widespread distribution }\end{array}$ & $\begin{array}{l}\text { Fire-sensitive species will have a } \\
\text { more widespread distribution }\end{array}$ & $\begin{array}{l}\text { Fire-sensitive species will have a } \\
\text { more widespread distribution }\end{array}$ \\
\hline Thickets & $\begin{array}{l}\text { Patchy, often associated with increase } \\
\text { in soil moisture or small disturbances }\end{array}$ & Common & Common \\
\hline Canopy gap structure & Dominated by large gaps & A wide variety of gaps & $\begin{array}{l}\text { Dominated by small-medium size } \\
\text { gaps. Larger gaps restricted to moisture } \\
\text { extremes, e.g., xeric sites and wet areas }\end{array}$ \\
\hline Crown closure & Relatively open & Variable & Variable \\
\hline $\begin{array}{l}\text { Vertical and horizontal } \\
\text { heterogeneity }\end{array}$ & Very patchy arrangement of trees & $\begin{array}{l}\text { Extremely patchy arrangement } \\
\text { of trees }\end{array}$ & $\begin{array}{l}\text { Moderately patchy arrangement } \\
\text { of trees }\end{array}$ \\
\hline Small woody debris $<10 \mathrm{~cm}$ & $\begin{array}{l}\text { Will vary from low to high } \\
\text { depending on time since fire }\end{array}$ & Generally high & Moderate \\
\hline Medium woody debris $10-30 \mathrm{~cm}$ & Low abundance of old logs & $\begin{array}{l}\text { Moderate to high abundance of logs } \\
\text { in a variety of decay and sizes }\end{array}$ & $\begin{array}{l}\text { Moderate to high abundance of logs } \\
\text { in a variety of decay and sizes }\end{array}$ \\
\hline Large woody debris $>35 \mathrm{~cm}$ & Low abundance of old logs & $\begin{array}{l}\text { Moderate to high abundance of logs } \\
\text { in a variety of decay stages }\end{array}$ & $\begin{array}{l}\text { Moderate abundance of logs in a } \\
\text { variety of decay stages }\end{array}$ \\
\hline
\end{tabular}

${ }^{1}$ Refers to chracateristics that can apply to grasslands.

Current conservation approaches used in the Montane Cordillera include, at the landscape level: protected areas, special management zones for umbrella species (mountain caribou, grizzly bear), visual quality, and old-growth management areas. At the stand level: wildlife tree patches, wildlife habitat areas for identified wildlife, and the coarse woody debris management strategy. Although these efforts will help minimize our impact on old-growth-dependent species, the overall efficacy of these measures is unknown. A rigorous and coordinated effort to implement and assess the current conservation approach is needed. Such an effort should use ecological principles in the short-term implementation (Klenner and Arsenault, in prep.) and use a combination of monitoring, research, and modelling to assess the current conservation approach.

\section{Acknowledgements}

I would like to warmly thank the organizers of the Old-growth Symposium for giving me the opportunity to share my enthusiasm and thoughts on old-growth forests. Gary E. Brad- field and Craig Delong made useful suggestions on an earlier version of this paper. Two anonymous reviewers also provided valuable advice. Many of the ideas in this paper are from work in progress with colleagues Trevor Goward and Walt Klenner. Dennis Lloyd kindly provided access to some superb photographs. Many thanks to Russ Walton for preparing figure 1 .

\section{References}

Achuff, P.L. 1989. Old-growth forests of the Canadian Rocky Mountain national parks. Natural Areas Journal 9(1): 12-26.

Antos, J.A. and R. Parish. 2002. Structure and dynamics of a nearly steady-state subalpine forest in south-central British Columbia, Canada. Oecologia 130: 126-135.

Arsenault A. 1995. Pattern and process in old-growth temperate rainforests of southern British Columbia. Dissertation, University of British Columbia, Vancouver, British Columbia.

Arsenault, A. and G.E. Bradfield. 1995. Structuralcompositional variation in three age classes of temperate rainforests of southern-coastal British Columbia. Canadian Journal of Botany 73: $54-64$. 
Arsenault, A. and T. Goward. 2000. Ecological characteristics of inland rainforests. In L. Darling (ed.). Proceedings of a Conference on the biology and management of species and habitats at risk. February 15-19 UCC, pp. 759-766. Kamloops, British Columbia. Arsenault, A. and T. Goward. (in prep.) Patterns of macrolichen diversity in old and young unmanaged forests along a moisture gradient in humid inland British Columbia.

Arsenault, A. and E. Klenner. 2001. Fire and dynamics of dry-belt forests: perception versus reality. In D. Falat and A. Klondenberg (eds.). Reintroduction of fire as a natural management tool: an ecosystem based approach. Proceedings of a workshop held on November 16th, 2000. pp. 15-17. Kamloops, British Columbia.

Arsenault, A. and W. Klenner. (In prep.) An overview of the fire regime and ecological characteristics of old-growth ecosystems of the dry-belt of British Columbia.

Banner, A., W. MacKenzie, S. Haeussler, S. Thomson, J. Pojar and R. Trowbridge. 1993. A field guide to site identification and interpretation for the Prince Rupert Forest Region. Land Management Handbook. No. 26. BC Minister of Forests, Research Branch, Victoria, British Columbia.

Baker, W.L. and D. Ehle. 2001. Uncertainty in surface-fire history: the case of ponderosa pine in the western United States. Canadian Journal of Forest Research 31: 1205-1226.

BC Ministry of Forests. 1992. Old growth strategy for British Columbia. Ministry of Forests. Victoria, British Columbia. 74 p.

BC Ministry of Forests and BC Environment. 1995. Biodiversity guidebook-forest practices code of British Columbia. Ministry of Forests and Ministry of Environment. Victoria, British Columbia. $99 \mathrm{p}$.

BC Ministry of Forests and Ministry of Environment, Lands and Parks. 1999. Landscape unit planning guide. Ministry of Forests and Ministry of Environment, Lands and Parks. Victoria, British Columbia. $101 \mathrm{p}$.

Braumandl, T.F. and M.P. Curran. 1992. A field guide for site identification and interpretation for the Nelson Forest Region. BC Ministry of Forests, Research Branch, Land Management Handbook No. 20. Victoria, British Columbia.

Carey, A.B. 1989. Wildlife associated with old-growth forests in the Pacific Northwest. Natural Areas Journal 9(3): 151-162.

Carey, A.B., J.A. Reid and S.P. Horton. 1990. Spotted owl home range and habitat use in southern Oregon coast ranges. Journal of Wildlife Management 54(1): 11-17.

Daigle, P. 1996. Fire in the dry interior forests of British Columbia. Extension Note.

DeLong, C. 1996a. A field guide for site identification and interpretation for the rocky mountain trench portion of the Prince George Forest Region. BC Ministry of Forest, Research Branch, Draft field guide insert. (Update for LMH 15.) Victoria, British Columbia.

DeLong, C. 1996b. A field guide for site identification and interpretation for the southeast portion of the Prince George Forest Region. BC Ministry of Forest, Research Branch, Draft field guide insert. Victoria, British Columbia.

DeLong, C., D. Tanner and M.J. Jull. 1993. A field guide for site identification and interpretation for the southwest portion of the Prince George Forest Region. BC Ministry of Forest, Research Branch, Land Management Handbook No. 24. Victoria, British Columbia.

DeLong, C., D. Tanner and M.J. Jull. 1994. A field guide for site identification and interpretation for the northern Rockies portion of the Prince George Forest Region. BC Ministry of Forest, Research Branch, Land Management Handbook No. 29. Victoria, British Columbia.

Drury, W.H. and I.C.T. Nisbet. 1973. Succession. Journal of the Arnold Arboretum. 54: 331-368.

Edwards. R.Y., J. Soos and R.W. Ritcey. 1960. Quantitative observations on epidendric lichens used as food by caribou. Ecology 41: 425-431.
Egler, F.E. 1954. Vegetation science concepts. I. Initial floristic composition: a factor in old-field vegetation development. Vegetatio 4: 412-417.

Franklin, J.F., K. Cromack, W. Denison, A. Mckee, C. Maser, J. Sedell, F. Swanson and G. Juday. 1981. Ecological characteristics of old-growth Douglas-fir forests. USDA Forest Service Technical Report PNW-118 Pacific Northwest Forest and Range Exp. Stn., Portland, Oregon. 48 p.

Gayton, D. 1996. Fire-maintained ecosystems and the effects of forest ingrowth. Extension Note.

Goward T. and A. Arsenault. 2000a. Cyanolichens and conifers: implications for global conservation. Forest Snow Landscape Research 75(3): 303-318.

Goward, T. and A. Arsenault. 2000b. Inland old-growth rainforests: safe havens for rare lichens? In L. Darling (ed.). Proceedings of a Conference on the biology and management of species and habitats at risk. pp. 437-439. February 15-19, UCC, Kamloops, British Columbia.

Goward, T. and A. Arsenault. (in prep.) Patterns of calicioid diversity in old and young unmanaged forests along a moisture gradient in humid inland British Columbia.

Holt, R.F., Braumandl and D.J. Mackillop. 1999. An index of old-growthness for two BEC variants in the Nelson Forest Region. Report prepared for Inter-agency Management Committee, Land Use Coordination Office, Ministry of Environment, Lands and Parks.

Hunter, M.L. Jr. and A.S. White. 1997. Ecological thresholds and the definition of old-growth Stands. Natural Areas Journal 17(4): 292-296. Kaufmann, M.R., W.H. Moir and W.W. Covington. 1992. Old-growth forests: what do we know about their ecology and management in the southwest and Rocky Mountain Regions. In M.R. Kaufmann, W.H. Moir, and R.L. Bassett, (eds.). Old-growth forests in the southwest and rocky mountain regions. Proceedings of a workshop. pp. 1-11. USDA, General Technical Report RM-213.

Klenner. W., L. Kremsater and A. Arsenault. (in prep.) Natural and managed disturbances in NDT4 forest types: A literature review and analysis of issues that relate to future management directions. (First draft for review.)

Klenner, W. and A. Arsenault. (In prep.) Ecological considerations in the development of an old-growth strategy for dry forest types (NDT4) in the Kamloops Forest Region.

Kneeshaw, D. and P. Burton. 1998. Assessment of functional old-growth status: a case study in the sub-boreal spruce zone of British Columbia, Canada. Natural Areas Journal 4: 293-308.

Lloyd, D., K. Angove, G. Hope and C. Thompson. 1990. A guide to site identification and interpretation for the Kamloops Forest Region. BC Ministry of Forests, Research Branch, Land Management Handbook No. 23. Victoria, British Columbia.

McCune, B. and T.F.H. Allen. 1985. Will similar forests develop on similar sites? Canadian Journal of Botany 63: 367-376.

Mehl, M.S. 1992. Old-growth descriptions for the major forest cover types in the rocky mountain region. In M.R. Kaufmann, W.H. Moir, and R.L. Bassett (eds.). Old-growth forests in the southwest and rocky mountain regions. Proceedings of a workshop. pp. 106-120.USDA, General Technical Report RM-213.

Meidinger, D. and J. Pojar (comps. and eds.). 1991. Ecosystems of British Columbia. BC Ministry of Forests Special Report Series No. 6. 330 p.

Newmaster, S.G., R.J. Belland, A. Arsenault and D.H. Vitt. 2003. Patterns of bryophyte diversity in the humid coastal and inland cedar-hemlock forests of British Columbia. Environmental Reviews (in press).

Old-growth definition task group. 1986. Interim definitions for oldgrowth Douglas-fir and mixed conifer forests in the Pacific Northwest and California. USDA Research Note PNW 447.

Oliver, C.D. 1981. Forest development in North America following major disturbances. Forest Ecology and Management 3: 152-168. 
Parish, R. 1997. Age and size structure of the forest at Sicamous Creek. In C. Hollstedt and A. Vyse (eds.). Sicamous Creek Silvicultural Systems Project: Workshop proceedings, April 24-25, 1996. pp. 16-31. BC Ministry of Forests Research Program. Working Paper 24.

Pickett, S.T.A. and P.S. White (eds.). 1985. The ecology of natural disturbance and patch dynamics. Academic Press, New York, NY. Rose, F. 1976. Lichenological indicators of age and environmental continuity in woodlands. In D.H. Brown, D.L Hawksworth, and R.H. Bailey (eds.). Lichenology: progress and problems. pp. 279-307. Academic Press, London.

Selva, S.B. 1994. Lichen diversity and stand continuity in the northern hardwoods and spruce-fir forests of northern New England and western New Brunswick. The Bryologist 97: 424-429.

Shinneman, D.J. and W.L. Baker. 1997. Nonequilibrium dynamics between catastrophic disturbances and old growth forests in Ponderosa Pine landscapes of the Black Hills. Conservation Biology $11: 1276-1288$.

Sloan, G. 1956. Forest resources of British Columbia. Report of the Commissioner. Victoria, British Columbia. 888 p.

Smaill, G.E. 1980. Seasonal effects of fire on ponderosa pine/bunchgrass range and Douglas fir/pinegrass range. Thesis, Washington State University, Seattle, WA. 83 p.

Söderström, L. 1988. The occurrence of epixylic bryophyte and lichen species in an old natural and managed forest stand in northwest Sweden. Biological Conservation 45: 169-178.

Spies, T. and J.F. Franklin. 1988. Old-growth and forest dynamics in the Douglas-fir region of western Oregon and Washington. Natural Areas Journal 8(3): 190-201.
Sprugel , D.G. 1991. Disturbance, equilibrium, and environmental variability: what is "natural" vegetation in a changing environment? Biological Conservation 58: 1-18.

Steeger C., H. Machmer, H. Pinnell and G. Smith. 2000. Deer Creek Wildlife Management Plan. Report prepared for the Columbia Basin Fish \& Wildlife Compensation Program, Nelson, British Columbia. Steen, O.A. and R.A. Coupé. 1997. A field guide to forest site identification and interpretation for the Cariboo Forest Region. BC Ministry of Forests, Research Branch. Land Management Handbook No. 39. Victoria, British Columbia.

Stevenson, S., H.M. Armleder, M.J. Jull, D.G. King, B.N. McLellan and D.S. Coxson. 2001. Mountain caribou in managed forests: recommendations for managers. Ministry of the Environment, Lands and Parks, Wildlife Branch, 2001. Victoria, British Columbia. 58 p. Tibell, L. 1992. Crustose lichens as indicators of forest continuity in boreal conifer forests. Nordic Journal of Botany 12: 427-450.

Timoney, K. 2001. Types and attributes of old-growth forests in Alberta, Canada. Natural Areas Journal. 21(3): 282-300.

Watt, A.S. 1947. Pattern and process in the plant community. Journal of Ecology 35: 1-22.

Wells, R.W., K.P. Lertzman and S.C. Saunders. 1998. Oldgrowth definitions for the forests of British Columbia, Canada. Natural Areas Journal 18(4): 279-292.

Whittaker, R.H. 1975. Communities and ecosystems. Macmillan, New York, NY. 